\title{
Compliance with school nutrition policy in Saudi Arabia: a quantitative study
}

Khalid Aldubayan ${ }^{1}$ and Mary Murimi ${ }^{2}$

${ }^{1}$ Community Health Sciences Department - Clinical Nutrition, College of Applied Medical Sciences, King Saud University, Saudi Arabia. ${ }^{2}$ Department of Nutritional Sciences, College of Human Sciences, Texas Tech University, United States of America. (Correspondence to: Khalid Aldubayan: kaldubayan@ksu.edu.sa).

\begin{abstract}
Background: An evidence-based school nutrition policy that helps increase the availability and accessibility of healthy foods is needed in the Kingdom of Saudi Arabia.

Aims: This study investigated the compliance of selected schools with Saudi nutrition policy and assessed the nutritional value of food offered in such schools using the Institute of Medicine (IOM) standards.

Methods: A total of 76 boys public high schools were randomly selected from four areas in Riyadh, Saudi Arabia. Principals and canteen managers were interviewed using validated questionnaires. Schools were observed using a food checklist.

Results: Meals offered in Saudis schools come prepackaged with minimal cooking in schools. From a calorie perspective, there was not a significant difference between the food allowed and food not allowed. For the Saudi policy, $94.7 \%$ of the schools scored in between category 2 and 3 (moderate compliance). For the IOM standards, $96.1 \%$ of the schools scored in category 1 (low alignment).
\end{abstract}

Conclusions: While the Saudi policy is clear on what should not be served in school cafeterias, it fails to provide guidance on what must be served to improve the nutritional value of meals provided.

Keywords: Nutrition; school meals; breakfast; Institute of Medicine, policy

Citation: Aldubayan K; Murimi M. Compliance with school nutrition policy in Riyadh, Saudi Arabia: a quantitative study. East Mediterr Health J. 2019;25(4):230-238. https://doi.org/10.26719/emhj.18.034

Received: 06/11/16; accepted: 01/10/17

Copyright @ World Health Organization (WHO) 2019. Some rights reserved. This work is available under the CC BY-NC-SA 3.0 IGO license (https:// creativecommons.org/licenses/by-nc-sa/3.o/igo).

\section{Introduction}

Childhood obesity is considered a pandemic in high-income as well as certain low-and middle-income countries. In the United States of America, the prevalence of obesity was $16.9 \%$ (38.1 million) among the youth (1). According to a Saudi national survey $(\mathrm{n}=19317$ children aged 5-18 years), the prevalence of overweight, obesity, and morbid obesity was $23.1 \%, 9.3 \%$ and $2 \%$, respectively (2). In Riyadh, two cross-sectional studies showed that the proportion of obese children rose steadily from $3.4 \%$ in 1988 to $24.5 \%$ in 2005 (3). During that period, the mean BMI increased from 16.5 to $18.0 \mathrm{~kg} / \mathrm{m}^{2}$, and fat percentage jumped from 13.2 to $19.7 \%$ (3). Obese children are more likely to be obese during adulthood, and this increases the risk of health complications, such as cardiovascular diseases and metabolic syndrome, at an early age (4). Cardiovascular diseases were the leading cause of death among males and females in Saudi Arabia from 1990 until 2010 (5).

According to the World Health Organization (WHO) (2015), the primary cause of overweight and obesity is a lifestyle that leads to energy imbalance between calories consumed and calories expended (6). For example, consuming energy-dense foods, which are high in fat and sugar, and performing low physical activity could lead to obesity. Studies conducted in different regions of Saudi Arabia found a trend among adolescents of skipping breakfast and consuming more foods high in sugar and fat rather than fiber and nutrient-dense foods such as fruits and vegetables (7-12). In Riyadh (Central Region) a study showed that the mean frequency intake per week of fruits and vegetables among adolescents aged 14-19 were 2.82 and 3.79 respectively (8). In addition, the mean frequency intake per week of sugar-sweetened drinks and sweets were 4.74 and 3.62 (9).

Moreover, according to WHO (2015), the high availability and accessibility of energy-dense foods with lack of supportive policies increase the consumption of these foods (10). In Saudi Arabia, the Ministry of Education (MoE) established the "Regulations of Health Conditions for School Canteens" in 2004 and updated the regulations in 2013 (11). This policy falls under the responsibilities of the General Administration of School Health (12). One of the five chapters is concerned with food offered in school canteens (13) and contains a list of banned food items, namely: confectioneries, chocolates, chips, soda, sport drinks, sweetened beverages, all meat products, and fried foods (14). We are not aware of other studies examining the effectiveness of the Saudi policy regarding this chapter on students' weight and eating habits. It is believed that a lack of detail concerning the nutritional content of food that should be offered as detailed by the Saudi canteen policy could allow offering food that is high in fat and sugar.

Having school nutrition policies that help increase 
the availability and accessibility of healthy foods is required. These policies could help in creating healthy school environments by providing healthy food choices. In the United States, several studies demonstrated the importance of a school nutrition policy that decreases the availability of energy-dense foods and increases the availability of healthy foods (13-17). The Institute of Medicine (IOM) school nutrition standards were used in this study since they offer recommendations for increasing the availability of nutritious foods and decreasing the availability of energy-dense foods in the United States (18). A review article that collected data from the Centers for Disease Control and Prevention (CDC) showed that schools in US states with policies more closely aligned with the IOM standards had low availability of the following foods: chocolate, candy, soda, sports drinks, and caffeinated foods or beverages (19).

The purpose of this study is threefold: first, to investigate the compliance of randomly selected boys' public high schools with the Saudi policy chapter "Meals and beverages offered in school canteens"; second, to assess the nutritional content of food offered as breakfast in Saudi boys' public high schools based on IOM school nutrition standards; and third, to determine the differences between schools' alignment scores and their location and report if they are adopting the Saudi policy.

\section{Methods}

\section{Sample and procedures}

In this study, 76 public high schools were randomly and evenly selected from four areas in Riyadh (19 north, 19 south, 19 east, and 19 west). In each area, simple randomization methods were used in the selection of the 19 schools to avoid sampling and non-coverage errors. This study included only boys' public high schools in Riyadh, Saudi Arabia. The sample size was measured with 95\% confidence level and with $\pm 5 \%$ margin of error. According to the Saudi Central Department of Statistics and Information (CDSI) (2015), there are 120 boys' public high schools in Riyadh city (20). Our sample size represents $63.3 \%$ of the total population.

Two research assistants were trained by principle investigators on the protocol of data collection. Both the school principal or representative and canteen managers were interviewed to investigate the compliance of their school with the Saudi policy regarding "Meals and beverages offered in school canteens." Our observations were used to assess the type of foods offered in the selected boys' public high schools in Riyadh; this information was used to estimate nutritional content of the foods such as calories, fat, saturated fat, trans-fat, sugar, sodium, and caffeine by using IOM school nutrition standards $(18,21)$.

\section{Measurements}

The following scoring system was used: o indicated that the school did not meet the standards' requirement, and 1 indicated that it did meet the requirement. Schools were categorized into quartiles based on their compliance with the Saudi policy. The banned food list consists of eight items: confectioneries, chocolates, chips, soft drinks, energy drinks, sweetened drinks, meat products, and fried foods (8). The possible total scores ranged from 0 to 8 , with o representing a low compliance score and 8 representing a high compliance score. The total possible scoring range in each quartile was:

- Quartile 1 (compliance score from o to 2), which is equivalent to $0-25.0 \%$

- Quartile 2 (compliance score from 3 to 4 ), which is equivalent to $25.1-50.0 \%$

- Quartile 3 (compliance score from 5 to 6), which is equivalent to $50.1-75.0 \%$

- Quartile 4 (compliance score from 7 to 8 ), which is equivalent to $75.1-100.0 \%$

For assessing the nutritional compositions of food offered in the selected schools using IOM standards, the CDC's scoring system was used (18), which ranges from $0-2$, with 0 indicating the food item did not meet the standards' requirement, 1 indicating that the food item partially met the standards' requirement, and 2 indicating that the food item met the standards' requirement. The IOM standards consist of 13 elements: four Standards for Nutritive Food Components, two Standards for Nonnutritive Food Components, five Standards for the School Day, and two Standards for the After-School Setting (21). Four IOM standards (marketing, allowing, and providing foods or beverages for high school students after school, and comparing à la carte entrée items with the National School Lunch Program [NSLP]), are not relevant to the Saudi school system and were excluded in our study. Breakfast and lunch meals are usually offered in US schools (22), whereas only breakfast is usually offered in Saudi schools $(8,23)$. The nine selected relevant standards consist of 21 variables (18). The possible total scores ranged from 0 to 42 , with 0 representing a low alignment score and 42 representing a high alignment score. The total possible scoring range in each quartile was:

- Quartile 1 (alignment score from o to 10.5), which is equivalent to $0-25.0 \%$

- Quartile 2 (alignment score from 10.51 to 21), which is equivalent to $25.1-50.0 \%$

- Quartile 3 (alignment score from 21.01 to 31.5), which is equivalent to $50.1-75.0 \%$

. Quartile 4 (alignment score from 31.51 to 42 ), which is equivalent to $75.1-100.0 \%$

The questionnaires for both the schools' principals and canteen managers were designed to measure the schools' compliance with the Saudi school nutrition policy regarding "Meals and beverages offered in school canteens." In these questionnaires, some questions were adopted from validated questionnaires used in a previous study (24). These questionnaires were validated by experts in nutrition, policy evaluation, research design, and statistics (consensual validity). In our study, 
observational notes and food check list were designed to assess the nutritional compositions of food offered in the selected schools. Food items offered in schools were analyzed based on the manufacturer food labels. Permission to conduct data from public Saudi schools was granted from the Saudi Ministry of Education (reference no. 3496858). The Human Research Protection Program (HRPP) at Texas Tech University ethically approved this study (registration no. 504382).

\section{Data Analysis}

Data were statistically analyzed by SPSS statistics 22 software. The homogeneity of the demographic data among schools' location (North, South, West, and East) was tested. The primary study goal was to measure the differences between schools' compliance and alignment scores among schools' area and the schools' principals report if they adopted the Saudi policy (adopting schools vs. non-adopting schools). A t-test was used to measure any significant difference between means of the two groups, while One Way ANOVA was used to test significant difference among means of more than two groups. The significance power and effect size of the difference between schools' compliance and alignment scores among schools' area were also measured. A chi-square test of independence was run to examine the relation between schools' locations and their alignment score categories for each of the IOM standards. Differences were considered statistically significant when $P<0.05$.

\section{Results}

A total of 152 participants were interviewed from 76 boys' public high schools; half of those were school principals and half were canteen managers. Most school principals ranged in age from 30 to 40 years $(42.1 \%)$ or from 41 to 50 (51.4\%). A bachelor's degree was the highest educational level for slightly more than three quarters $(78.9 \%)$ of the school principals. $21.1 \%$ of the school principals had $\geq 5$ years' experience of working as principals, $46.1 \%$ of them had between 5 to 10 years' experience, and $23.7 \%$ of them had between 11 to 15 years' experience. Younger school principals were more likely to be in the Northern and Southern regions of Riyadh $\chi^{2}(15, N=76)=23.801, P<$ 0.05 , with no significant difference in other demographic characteristics. Therefore, the four groups based on school locations are almost homogeneous. Other demographical characteristics for both the interviewed school principals and the visited schools are provided in Table 1.

For the Saudi school nutrition policy, $44.7 \%$ (25) of the schools scored in category 2, 50\% (38) of the schools scored in category 3, and 5.3\% (4) of the schools scored in category 4 . There is no significant correlation between

\begin{tabular}{|c|c|c|c|c|}
\hline Variables & $\%(n)$ & Mean (SD) & Range & $\boldsymbol{P}$ values \\
\hline \multicolumn{5}{|l|}{ School location } \\
\hline North of Riyadh & $25 \%(19)$ & & & \\
\hline South of Riyadh & $25 \%(19)$ & & & \\
\hline East of Riyadh & $25 \%(19)$ & & & \\
\hline West of Riyadh & $25 \%(19)$ & & & \\
\hline Principals' age range & & & & $0.013^{*_{a}}$ \\
\hline$(30-40)$ & $42.1 \%(32)$ & & & \\
\hline$(41-50)$ & $51.4 \%(39)$ & & & \\
\hline$(51-60)$ & $6.5 \%(5)$ & & & \\
\hline Principals' education level & & & & $0.979^{\mathrm{a}}$ \\
\hline Bachelor Degree & $78.9 \%(60)$ & & & \\
\hline Master Degree & $21.1 \%(16)$ & & & \\
\hline Principals' experience & & & & $0.528^{a}$ \\
\hline$<5$ years & $21.1 \%(16)$ & & & \\
\hline $5-10$ years & $46.1 \%(35)$ & & & \\
\hline $11-15$ years & $23.7 \%(18)$ & & & \\
\hline $16-20$ years & $5.3 \%(4)$ & & & \\
\hline$>20$ years & $3.9 \%(3)$ & & & \\
\hline Number of students enrolled & & $340.42(105.93)$ & $140-580$ & $0.164^{b}$ \\
\hline $\begin{array}{l}\text { Number of students registered in the Saudi } \\
\text { social security system }\end{array}$ & & $14.22(12.80)$ & $0-50$ & $0.267^{\mathrm{b}}$ \\
\hline Graduation rate & & $0.89(0.05)$ & $0.80-0.99$ & $0.191^{\mathrm{b}}$ \\
\hline
\end{tabular}

${ }^{a} P$ values of chi-square test regarding the differences among schools' locations. P values of Fisher's exact test were reported because some of the expected cells were $<5$.

${ }^{b} \mathrm{P}$ values of One-Way ANOVA test regarding the differences among schools' locations.

*Significance level at $P<0.05$. 
the schools' compliance with the Saudi policy regarding "Meals and beverages offered in school canteens" and demographical variables. There were no significant differences between schools' locations and schools' compliance scores with the Saudi policy regarding the banned foods list, $F(3,72)=1.296, P=0.282$. There was no statistically significant difference between adopting schools $(5.25 \pm 1.42)$ and non-adopting schools $(4.67 \pm 1.11)$ in regards to their compliance scores with banned foods list in the Saudi policy, $t(74)=1.578, P=0.119$. This result was reported from $t$ test with assumed equal variance, Levene's $F(1,74)=0.941, P=0.335$.

For the IOM standards, 96.1\% (73) of the schools scored in category 1, and 3.9\% (3) of the schools scored in category 2. There is no significant correlation between the alignment scores to the IOM standards and the demographical variables. There were significant differences between schools' locations and schools' alignment scores to the IOM school nutrition standards, $F(3,39.555)=4.245, P=0.011$ (see Table 2 ) . This significant result was reported from Welch test because of unequal variances, Levene's $F(3,72)=4.209, P=0.008$. According to the Tukey post hoc test, schools located in the East of Riyadh had significantly higher alignment scores to the IOM standards compared to schools located north of Riyadh $(1 \pm .363$ scores, $P=0.036)$ and schools located south of Riyadh $(1 \pm .363$ scores, $P=0.036)$. Schools in the east of Riyadh were more diligent in prohibiting carbonated, fortified, and flavoured waters, $\chi^{2}(3, N=76)=12.179, P$ $<0.01$ (see Table 3 ). There was no statistically significant difference between adopting schools $(8.75 \pm 1.21)$ and non-adopting schools $(9.06 \pm 1.18)$ with regards to their alignment scores to IOM school nutrition standards, $t(74)$ $=-0.838, P=0.405$. This result was reported from $t$ test with assumed equal variance, Levene's $F(1,74)=0.312, P$ $=0.578$.

The significance power of Welch test was calculated based on the sample size in each group and their effect sizes. The effect sizes were measured based on the means and standard deviation differences between the groups according to school locations. The effect size (Cohen's $d$ ) of schools located east of Riyadh compared to schools located north of Riyadh was 1.0115. This effect size and sample size, equal to 19 in each group, yield power equal to 0.86 , which is acceptably high. In addition, the effect size (Cohen's $d$ ) of schools located east of Riyadh compared to schools located south of Riyadh was 0.825 . This effect size and sample size, equal to 19 in each group, yield power equal to 0.697 , which is also acceptably high. Moreover, the normality of the schools' alignment scores to IOM standards was statistically tested by Shapiro-Wilk test. The results showed that the schools alignment scores to IOM standards were significantly normal, $W(76)=.873$, $P=0.000$.

Concerning food offered in schools, all 76 schools offered prepackaged food, namely: cheese puffs, apple puffs, plain croissant, cheese croissant, and zaatar croissant (roasted thyme with sesame seeds). These prepacked foods contain more energy, fat, and saturated fat than what is recommended by IOM standards (see Table 4). Compared to a sample of commonly banned foods in the Saudi policy, these prepacked foods provide similar total calories and percentage of total calories from fat per portion as packaged (see Table 5). This comparison did not look at other nutrients.

Eleven schools indicated that they prepared fried foods such as fried potatoes and while two schools reported preparing $100 \%$ fresh fruit juices. Three of the 76 schools had vending machines that carried some or all of the following: bottled plain water, whole fat milk, flavoured whole fat milk, artificially flavoured drinks, chips, candies, prepackaged cakes, and chocolate bars. Although bottled water was available for sale in all schools, 63 schools had working water fountains. Cakes and muffins were available in 75 schools, confectionaries were available in 73 schools, and biscuits and cookies were available in 71 schools. Chips were available in 40 schools, which is slightly above half of the selected schools. None of the 76 schools carried fruits or vegetables.

\section{Discussion}

The results showed that the compliance score of most of the selected schools in Riyadh (94.7\%) with the requirements of the Saudi policy regarding "Meals and beverages offered in school canteens" ranged from $25 \%$ to $75 \%$. These results indicated moderate compliance of boys' public high schools in Riyadh to the Saudi policy. Although no percentage was reported, a similar trend was found in the Gulf region. According to the World Cancer Research Fund (2015), the compliance of Kuwaiti public schools with banned foods monitored by the Kuwaiti Ministry of Education was not high (26).

The results also showed that the alignment of the majority of the selected schools in Riyadh (96.1\%) met

$\begin{aligned} & \text { Table } 2 \text { ANOVA results for the difference between school Location and school alignment scores with IOM school nutrition } \\
& \text { standards }\end{aligned}$ N
\begin{tabular}{llcccc} 
Schools Locations & Mean & SD & F value & P value \\
North of Riyadh & 19 & $8.58 \mathrm{a}$ & 1.07 & $4.245 \mathrm{~d}$ & $0.011^{*}$ \\
South of Riyadh & 19 & $8.58 \mathrm{~b}$ & 1.46 & & \\
East of Riyadh & 19 & $9.58 \mathrm{a}, \mathrm{b}$ & 0.90 & & \\
West of Riyadh & 19 & 9.31 & 0.95 & & \\
\hline
\end{tabular}

a,bdenotes significant group differences in the Tukey post hoc test. $d$ Welch test was used because of unequal variances.

* Significance level at $P<0.05$. 


\begin{tabular}{|c|c|c|c|c|}
\hline \multirow[t]{2}{*}{ Schools Locations } & \multicolumn{2}{|c|}{ Prohibited carbonated, fortified and flavoured waters standard } & \multirow[t]{2}{*}{$x^{2}$} & \multirow[t]{2}{*}{$\boldsymbol{P}$-value } \\
\hline & Did fully meet the standard & Did not meet the standard & & \\
\hline North of Riyadh & 10 & 9 & 12.179 & $0.007^{*}$ \\
\hline South of Riyadh & 9 & 10 & & \\
\hline East of Riyadh & 16 & 3 & & \\
\hline West of Riyadh & 17 & 2 & & \\
\hline
\end{tabular}

${ }^{*}$ Significance level at $P<0.01$

$<25 \%$ of IOM standards. Similar results, reported by the CDC (2012), found that high schools in 25 out of 39 US states had an alignment score that ranged from $0 \%$ to $25 \%$. The present study found that none of the selected schools in Riyadh met the IOM recommendations for the percentage of total energy, fat, and saturated fat in foods offered as breakfast in school canteens. Results showed that foods available in the selected schools in Riyadh contain more energy, fat, and saturated fat than what is recommended by IOM standards. These results concur with a study conducted in the United States that $73.8 \%, 36.2 \%$, and $71.2 \%$ of students aged $5-13$ years selected foods that exceeded the upper limit of the IOM recommendations with total energy, fat, and saturated fat, respectively (27).

This study found that most prepackaged foods offered as breakfast in the selected boys' public high schools in Riyadh were energy-dense snacks such as cakes and muffins (98.7\%), confectionaries (96\%), biscuits and cookies (93.4\%), and chips (52.6\%). These results confirm the findings of a study conducted in the southern region of Saudi Arabia, which found that $87 \%$ of the food items available in the school canteens in Abha were energydense foods such as confectionaries, chips, cakes, cookies, pudding, and ice cream (28). Similarly, in the United States, a study found that $44 \%, 23 \%$, and $20 \%$ of 494 high schools offered doughnuts, biscuits, and muffins, respectively for breakfast (29).
The results of the present study found that neither sports drinks nor soft drinks were available in the selected schools in Riyadh. However, soft drinks were available in schools in Abha (28). The present study found that whole milk and flavoured whole milk were available in all selected schools in Riyadh. This result was consistent with Togoo et al. (2012), as whole milk and flavoured whole milk were also available in schools in Abha (28). On the contrary, schools in the United States offered more low-fat milk than whole-fat milk for breakfast (29). The present study also found that fresh fruit was not available in all selected boys' public high schools in Riyadh. However, based on the student reports, fresh fruit was available in $13 \%$ of the schools in Abha (28). In the United States, $50 \%$ of 494 high schools offered fresh fruit for breakfast (29).

The results of this study showed that schools in the east of Riyadh were more diligent in prohibiting carbonated, fortified, and flavoured waters compared to schools in the north and south of Riyadh. Results also showed that 24 out of 76 schools in Riyadh offered carbonated, fortified and flavoured waters, since these beverages were not listed in the Saudi policy as banned beverages. Offering these types of beverages could compete with the consumption of potable water in schools. The present study showed that bottled water was available for sale in all schools, and 63 out of 76 schools had working water fountains. In the United states, a study revealed that increasing the availability of competitive beverages and

\begin{tabular}{|c|c|c|c|c|c|c|}
\hline Food items & $\begin{array}{c}\text { Mean a } \\
\text { percentage of } \\
\text { total calories } \\
\text { from fat per } \\
\text { portion as } \\
\text { packaged }\end{array}$ & $\begin{array}{l}\text { Percentage above } \\
\text { IOM standards } \\
\text { for total calories } \\
\text { from fat }(\geq 35 \%)\end{array}$ & $\begin{array}{c}\text { Mean a }^{\text {a }} \\
\text { percentage of } \\
\text { total calories } \\
\text { from saturated- } \\
\text { fat per portion as } \\
\text { packaged }\end{array}$ & $\begin{array}{l}\text { Percentage above } \\
\text { IOM standards } \\
\text { for total calories } \\
\text { from saturated- } \\
\text { fat }(\geq 10 \%)\end{array}$ & $\begin{array}{c}\text { Mean a }^{\text {a }} \\
\text { percentage of } \\
\text { total calories } \\
\text { from sugar } \\
\text { per portion as } \\
\text { packaged }\end{array}$ & $\begin{array}{l}\text { Percentage above } \\
\text { IOM standards } \\
\text { for total calories } \\
\text { from sugar } \\
\quad(\geq 35 \%)\end{array}$ \\
\hline Cheese puffs & $54 \%$ & $19 \%$ & $16 \%$ & $6 \%$ & $40 \%$ & $5 \%$ \\
\hline Apple puffs & $46 \%$ & $11 \%$ & $16 \%$ & $6 \%$ & $51 \%$ & $16 \%$ \\
\hline Plain croissant & $52 \%$ & $17 \%$ & $13 \%$ & $3 \%$ & $42 \%$ & $7 \%$ \\
\hline Cheese croissant & $51 \%$ & $16 \%$ & $17 \%$ & $7 \%$ & $42 \%$ & $7 \%$ \\
\hline Zaatar $^{\text {b }}$ & $45 \%$ & $10 \%$ & $12 \%$ & $2 \%$ & $41 \%$ & $6 \%$ \\
\hline
\end{tabular}

${ }^{a}$ The mean percentage of total calories from fat, saturated-fat, and sugar of prepacked foods from various food manufacturers.

${ }^{b}$ Roasted thyme with sesame seeds. 


\begin{tabular}{|c|c|c|c|c|c|c|c|c|c|c|}
\hline \multirow[t]{2}{*}{ Food Items } & \multicolumn{5}{|c|}{ Allowed food items ${ }^{a}$} & \multicolumn{5}{|c|}{ Banned food items } \\
\hline & $\begin{array}{l}\text { Cheese } \\
\text { puffs }\end{array}$ & Apple puffs & $\begin{array}{c}\text { Plain } \\
\text { croissant }\end{array}$ & $\begin{array}{l}\text { Cheese } \\
\text { croissant }\end{array}$ & $\begin{array}{c}\text { Zaatar }^{\mathrm{b}} \\
\text { croissant }\end{array}$ & Chocolates $^{c}$ & Cakes $^{c}$ & Biscuits $^{c}$ & Sodas $^{\mathrm{d}}$ & Chips $^{e}$ \\
\hline $\begin{array}{l}\text { Mean }{ }^{\mathrm{f}} \\
\text { of total calories } \\
\text { per portion as } \\
\text { packaged (kcal) }\end{array}$ & 228 & 217 & 210 & 208 & 232 & 242 & 192 & 236 & 180 & 160 \\
\hline $\begin{array}{l}\text { Mean }{ }^{\mathrm{f}} \\
\text { percentage of } \\
\text { total calories } \\
\text { from fat per } \\
\text { portion as } \\
\text { packaged }\end{array}$ & $54 \%$ & $46 \%$ & $52 \%$ & $51 \%$ & $45 \%$ & $45 \%$ & $41 \%$ & $39 \%$ & - & $55 \%$ \\
\hline
\end{tabular}

${ }^{a}$ Nutritional information per $100 \mathrm{~g}$ portion.

${ }^{b}$ Roasted thyme with sesame seeds.

'Nutritional information per 50 g portion.

${ }^{d}$ Nutritional information per 12 US fl oz can, which is equivalent to $360 \mathrm{ml}$ can.

${ }^{e}$ Nutritional information per $28 \mathrm{~g}$ portion.

fThe mean of total calories and the mean percentage of total calories from fat of prepacked foods from various food manufacturers.

limiting the access to free water could be barriers in promoting potable water consumption in schools (30).

\section{Limitations}

There were several limitations with our study. First, this study focused only on Riyadh and our study's results cannot be generalized to schools in other cities in Saudi Arabia. Second, our study excluded female schools because only female investigators were allowed access, and the study was conducted by a male investigator. Therefore, we cannot generalize our study's results to female schools in Riyadh. Third, our study focused only on public high schools, and we cannot generalize our study's results to public elementary, public middle, and private schools in Riyadh. However, it is believed that this study is the first of its kind that investigates the compliance of boys' public high schools with the Saudi policy regarding "Meals and beverages offered in school canteens." It is also the first of its kind that uses IOM's school nutrition standards in the assessment of the Saudi policy and the nutritional content of foods offered as breakfast in boys' public high schools in Riyadh. Because the power of our sample size was measured, the significance reached is acceptable and the normality of the data was not violated; thus, our results can be generalized to male public high schools in Riyadh.

\section{Conclusion}

This study showed that the boys' public high schools in Riyadh had a moderate compliance to the Saudi policy regarding "Meals and beverages offered in school canteens." The Saudi Ministry of Education was effective in banning soda and sports beverages in Riyadh, since none of the selected public schools offered these drinks. However, the Saudi Ministry of Education needs to improve compliance of public schools in Riyadh with other banned food items and increase the availability of nutri- tious foods such as whole grains, fruit and vegetables. Further studies are required to investigate the compliance of public schools with the other four chapters of the Saudi policy. The present study also showed that the selected schools in Riyadh have a low alignment with IOM standards. This is to be expected, since the Saudi policy regarding "Meals and beverages offered in school canteens" lacks detail on nutritional content of food items allowed in school canteens compared to IOM standards. The present study showed that a sample of commonly offered prepacked foods provide similar total energy and percentage of total calories from fat per portion as packaged when compared to foods from the banned list in the Saudi policy. Therefore, permitted and banned food items in the Saudi policy need to be expanded based on evidence-based standards such as the IOM.

Although the selected schools had moderate compliance with the Saudi policy and that all schools banned soft drinks and energy beverages, $84 \%$ of schools reported that they did not adopt the Saudi policy. The reasons behind this discrepancy are unknown, as this study was not designed to examine this. Two studies showed that lack of funds, awareness, coordination, cooperation, resources, training and enforcement are possible barriers to implementing the school wellness policies in the United States and adopting nutrition guidelines in schools in Canada (31,32). In addition, two non-school studies conducted in Kenya and Nigeria showed that poor communication between policy-makers and policy implementers is a possible barrier to the low or moderate compliance to a policy $(33,34)$. A similar finding was reported in a Saudi study that poor communication between the Saudi Ministry of Health and health workers is one of the identified problems that face healthcare delivery in Saudi Arabia (25). Therefore, follow-up qualitative studies, such as focus groups, are required to identify barriers to adopting and implementing the Saudi policy. 
In order to offer healthy foods in schools in the six Gulf Cooperation Council (GCC) countries, the United Nations International Children's Emergency Fund (UNICEF) (2014) provided recommendations to their governments (35). The recommendations include introduction of a law that bans unhealthy items sold in school canteens, establishing a School Health Committee, and incorporating health education sessions as a mandatory component of the new school curriculum (35). Although the Saudi policy has a list of certain banned foods, our study showed that this list is not enough to ensure offering healthy foods and snacks for breakfast in schools. The present study showed that most of the food offered in the selected boys' public high schools were energy-dense foods that were high in fat and sugars. Therefore, it is highly recommended for policy-makers in the Saudi Ministry of Education to develop the Saudi policy regarding "Meals and beverages offered in school canteens" based on evidence-based standards such as the IOM. It is also recommended that the Saudi Ministry of Education source specialized nutritional advice in order to develop the Saudi policy.

\section{Funding: None.}

Competing interests: None declared.

\section{Respect de la politique nutritionnelle en milieu scolaire en Arabie saoudite : étude quantitative}

\section{Résumé}

Contexte : Le Royaume d'Arabie saoudite doit mettre en place une politique nutritionnelle en milieu scolaire qui repose sur des bases factuelles afin d'accroître la disponibilité et l'accessibilité d'aliments sains.

Objectifs : La présente étude a pour objectif d'examiner le respect par un certain nombre d'écoles de la politique de nutrition mise en place en Arabie saoudite et d'évaluer la valeur nutritionnelle des aliments proposés dans ces écoles à l'aide des normes de l'Institute of Medicine (IOM).

Méthodes : Au total, 76 établissements secondaires publics de garçons ont été sélectionnés au hasard dans quatre quartiers de Riyad (Arabie saoudite). Les proviseurs et les responsables de cantine ont été interrogés à l'aide de questionnaires validés. Une liste de contrôle des aliments a été utilisée pour observer les établissements scolaires.

Résultats : Les repas proposés dans les établissements scolaires saoudiens sont livrés sous forme préemballée et ne nécessitent qu'une remise en température sur place. Du point de vue des calories, aucune différence notable n'a été notée entre les aliments autorisés et les aliments non autorisés. En ce qui concerne la politique mise en place par le Royaume d'Arabie saoudite, le score obtenu par 94,7\% des établissements se situait entre la catégorie 2 et la catégorie 3 (niveau de conformité modéré). Pour ce qui est des normes de l'IOM, le score obtenu par 96,1\% des établissements se situait dans la catégorie 1 (niveau de conformité faible).

Conclusions : Bien que la politique mise en place par le Royaume d'Arabie saoudite indique clairement les aliments qui ne doivent pas être servis dans les cantines scolaires, elle ne formule pas d'orientations sur les aliments à privilégier pour améliorer la valeur nutritionnelle des repas fournis.

$$
\begin{aligned}
& \text { الامثثال لسياسة التغذية في المدارس في المملكة العربية السعودية: دراسة كمية } \\
& \text { خالد الدبيان، ماري موريمي } \\
& \text { الخالاصة } \\
& \text { الخلفية: يجب وضع سياسة تغذية قائمة على البراهين في المدارس تساعد على زيادة توافر الأغذية الصحية والحصول عليها في المملكة العربية } \\
& \text { السعودية. } \\
& \text { الأهداف: حققت هذه الدراسة في امتثال المدارس المحددة لسياسة التغذية السعودية، وقيّمت القيمة التغذوية للأغذية المقدَّمة في هذه المدارس المقد } \\
& \text { باستخدام معايي المعهد الطبي. }
\end{aligned}
$$

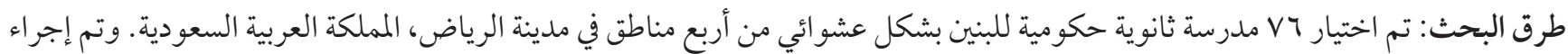

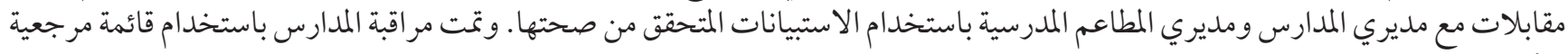

$$
\begin{aligned}
& \text { لأغذية. } \\
& \text { النتائج: تأتي الوجبات المقدَّمة في المدارس السعودية معلبة مسبقًا لا تحتاج إلا القليل من الطهي في المدارس. و ومن ناحية السعرات الحرارية، لا توجد }
\end{aligned}
$$

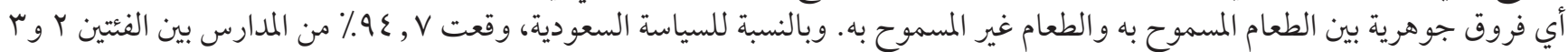

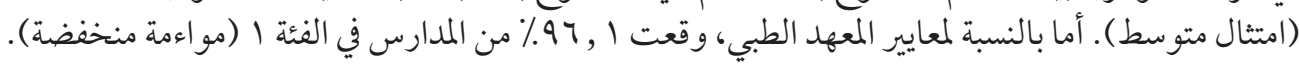

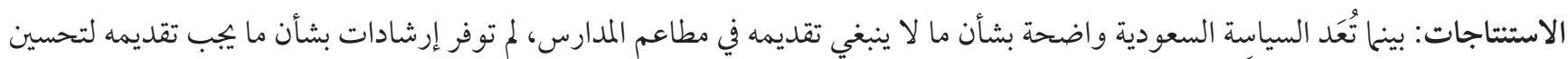

$$
\begin{aligned}
& \text { القيمة التغذوية للو جبات المقدَّمة. }
\end{aligned}
$$




\section{References}

1. Ogden CL, Carroll MD, Kit BK, Flegal KM. Prevalence of childhood and adult obesity in the United States, 2011-2012. JAMA. 2014;311(8):806-14. http://dx.doi.org/10.1001/jama.2014.732

2. El Mouzan MI, Foster PJ, Al Herbish AS, Al Salloum AA, Al Omer AA, Qurachi MM, et al. Prevalence of overweight and obesity in Saudi children and adolescents. Ann Saudi Med. 2010;30(3):203-8. http://dx.doi.org/10.4103/0256-4947.62833

3. Al-Hazzaa HM. Prevalence and trends in obesity among school boys in Central Saudi Arabia between 1988 and 2005 . Saudi Med J. 2007;28(10):1569-74.

4. Centers for Disease Control. Childhood obesity causes \& consequences. Atlanta: CDC; 2015 (http://www.cdc.gov/obesity/childhood/causes.html)

5. Memish ZA, Jaber S, Mokdad AH, AlMazroa MA, Murray CJ, Al Rabeeah AA. (2014). Burden of disease, injuries, and risk factors in the Kingdom of Saudi Arabia, 1990-2010. Atlanta: CDC. 2014(11):1-12.

6. World Health Organization. Obesity and overweight. Geneva: World Health Organization; 2015 (http://www.who.int/en/newsroom/fact-sheets/detail/obesity-and-overweight).

7. Al-Hazzaa HM, Abahussain NA, Al-Sobayel HI, Qahwaji DM, Musaiger AO. Physical activity, sedentary behaviors and dietary habits among Saudi adolescents relative to age, gender and region. Int J Behav Nutr Phys Act. 2011;8(1):140. http://dx.doi. org/10.1186/1479-5868-8-140

8. Ministry of Education. (2013). Regulations of Health Conditions for school canteens. (https://bit.ly/2zVysFj).

9. Al-Hazzaa HM, Abahussain NA, Al-Sobayel HI, Qahwaji DM, Musaiger AO. Lifestyle factors associated with overweight and obesity among Saudi adolescents. BMC Public Health. 2012;12(1):354. http://dx.doi.org/10.1186/1471-2458-12-354

10. Al Muammar MN, El-Shafie M, Feroze S. Association between dietary habits and body mass index of adolescent females in intermediate schools in Riyadh, Saudi Arabia. East Mediterr Health J. 2014;20(1):39-45. http://dx.doi.org/10.26719/2014.20.1.39

11. Amin TT, Al-Sultan AI, Ali A. Overweight and obesity and their relation to dietary habits and socio-demographic characteristics among male primary school children in Al-Hassa, Kingdom of Saudi Arabia. Eur J Nutr. 2008;47(6):310-8. http://dx.doi. org/10.1007/s00394-008-0727-6

12. Collison KS, Zaidi MZ, Subhani SN, Al-Rubeaan K, Shoukri M, Al-Mohanna FA. Sugar-sweetened carbonated beverage consumption correlates with BMI, waist circumference, and poor dietary choices in school children. BMC Public Health. 2010;10(1):1 (https://www.ncbi.nlm.nih.gov/pmc/articles/PMC2877673/pdf/1471-2458-10-234.pdf).

13. Bauhoff $S$. The effect of school district nutrition policies on dietary intake and overweight: a synthetic control approach. Econ Hum Biol. 2014;12:45-55. http://dx.doi.org/10.1016/j.ehb.2013.06.001

14. Cullen KW, Watson KB. The impact of the Texas public school nutrition policy on student food selection and sales in Texas. Am J Public Health. 2009;99(4):706-12. http://dx.doi.org/10.2105/AJPH.2007.129387

15. Cullen KW, Watson K, Zakeri I. Improvements in middle school student dietary intake after implementation of the Texas Public School Nutrition Policy. Am J Public Health. 2008;98(1):111-7. http://dx.doi.org/10.2105/AJPH.2007.111765

16. Kubik MY, Wall M, Shen L, Nanney MS, Nelson TF, Laska MN, et al. State but not district nutrition policies are associated with less junk food in vending machines and school stores in US public schools. J Am Diet Assoc. 2010;110(7):1043-8. http://dx.doi. org/10.1016/j.jada.2010.04.008

17. Mendoza JA, Watson K, Cullen KW. Change in dietary energy density after implementation of the Texas Public School Nutrition Policy. J Am Diet Assoc. 2010;110(3):434-40. http://dx.doi.org/10.1016/j.jada.2009.11.021

18. Centers for Disease Control. Competitive Foods and Beverages in U.S. Schools: A State Policy Analysis. Atlanta: CDC; 2012 (http:// www.cdc.gov/healthyyouth/nutrition/pdf/compfoodsbooklet.pdf).

19. Merlo CL, Olsen EO, Galic M, Brener ND. (2014). The Relationship Between State Policies for Competitive Food and School Nutrition Practices in the United States. Atlanta: CD; 2014:1-10.

20. Saudi Central Department of Statistics and Information. Government Services Statistics in Riyadh Region, 2015 (http://www. stats.gov.sa/sites/default/files/cdsi_data/dmdocs/g-serv-2015-riyadh.pdf).

21. Institute of Medicine. (2007, April 23). Nutrition Standards for Foods in Schools: Leading the Way Toward Healthier Youth (https://bit.ly/2y5fyu5).

22. USA education in brief. Washington, DC: United States Government; 2008 (https://photos.state.gov/libraries/amgov/30145/publications-english/education-brief.pdf).

23. Saudi Arabian Cultural Mission. Educational System in Saudi Arabia. 2006 (http://www.sacm.org/Publications/58285_Edu_complete.pdf).

24. Murimi M, Colvin J, Liner K, Guin J. Methodology to evaluate outcomes of the team nutrition initiative in schools. Washington, DC: United States Government; 2006 (http://naldc.nal.usda.gov/download/32793/PDF).

25. Al-Rabeeah A. The history of health care in the Kingdom of Saudi Arabia with emphasis on pediatric surgery. Saudi Med J. 2003;24(5):9-10.

26. World Cancer Research Fund. London: Offer healthy foods; 2015 (https://www.wcrf.org/int/policy/nourishing-framework/offerhealthy-foods). 
27. Martin CK, Thomson JL, LeBlanc MM, Stewart TM, Newton RL, Han H, et al. Children in school cafeterias select foods containing more saturated fat and energy than the Institute of Medicine recommendations. J Nutr. 2010;140(9):1653-1660 PMID 20668251 http://dx.doi.org/10.3945/jn.109.119131

28. Togoo RA, Meer Z, Kandlaya R, Yaseen SM, Al-Shehri TD, Al-Ghamdi HG. Availability of Cariogenic Foods in Primary School Canteens of Abha City, Saudi Arabia: A Cross-Sectional Study. WORLD. 2012;3(3):239-42.

29. Condon EM, Crepinsek MK, Fox MK. School Meals: Types of Foods Offered to and Consumed by Children at Lunch and Breakfast. J Am Diet Assoc. 2009;109(2):S67-78. http://dx.doi.org/10.1016/j.jada.2008.10.062

30. Patel AI, Hampton KE. Encouraging Consumption of Water in School and Child Care Settings: Access, Challenges, and Strategies for Improvement. Am J Public Health. 2011;101(8):1370-9. http://dx.doi.org/10.2105/AJPH.2011.300142

31. Budd EL, Schwarz C, Yount BW, Haire-Joshu D. (2012). Factors Influencing the Implementation of School Wellness Policies in the United States, 2009. Atlanta: CDC, 2012.

32. Downs SM, Farmer A, Quintanilha M, Berry TR, Mager DR, Willows ND, et al. From Paper to Practice: Barriers to Adopting Nutrition Guidelines in Schools. J Nutr Educ Behav. 2012;44(2):114-22. http://dx.doi.org/10.1016/j.jneb.2011.04.005

33. Glenngard AH, Maina TM. Reversing the trend of weak policy implementation in the Kenyan health sector? - a study of budget allocation and spending of health resources versus set priorities. Health Res Policy Syst. 2007;5(3):1-9.

34. Makinde T. Problems of Policy Implementation in Developing Nations: The Nigerian Experience. J Soc Sci. 2005;11(1):63-9.

35. United Nations International Children's Emergency Fund (UNICEF). Gulf Area. New York: UNICEF; 2014 (http://www.unicef.org/ about/execboard/files/2013-PL17-Gulf_Area_CPD-final_approved-English.pdf). 